\title{
The space of conflict: Aboriginal/ European interactions and frontier violence on the western Central Murray, South Australia, 1830-41
}

\author{
Heather Burke, Amy Roberts, Mick Morrison, Vanessa Sullivan and \\ the River Murray and Mallee Aboriginal Corporation (RMMAC)
}

Colonialism was a violent endeavour. Bound up with the construction of a market-driven, capitalist system via the tendrils of Empire, it was intimately associated with the processes of colonisation and the experiences of exploiting the land, labour and resources of the New World. ${ }^{1}$ All too often this led to conflict, particularly between Indigenous and non-Indigenous peoples. Overt violence (the euphemistic 'skirmishes', 'affrays' and 'collisions' of the documentary record), clandestine violence (poisonings, forced removals, sexual exploitation and disease) and structural violence (the compartmentalisation of Aboriginal people through processes of race, governance and labour) became routinised aspects of colonialism, buttressed by structures of power, inequality, dispossession and racism. Conflict at the geographical margins of this system was made possible by the general anxieties of life at, or beyond, the boundaries of settlement, closely associated with the normalised violence attached to ideals of 'manliness' on the frontier. ${ }^{2}$

The 'History Wars' that ignited at the turn of the twenty-first century sparked an enormous volume of detailed research into the nature and scale of frontier violence across Australia. Individual studies have successfully canvassed the

\footnotetext{
Silliman 2005.

Evans 1993: 33; Hogg 2011; Woollacott 2009.
} 
role of the Native Mounted Police, ${ }^{3}$ the semantics used to describe engagement, ${ }^{4}$ the nature of policing and judicial procedures ${ }^{5}$ and the specifics of particular massacres. ${ }^{6}$ While some have highlighted the need for more empirical research, ${ }^{7}$ historical archaeological perspectives on frontier conflict remain largely absent from the Australian literature. ${ }^{8}$ This is partly because the nature of conflict was so opportunistic and materially subtle that it is not amenable to conventional archaeological analysis. ${ }^{9}$ It is also the case that the mapping of frontier conflict is no straightforward matter, particularly when the documentation attached to it both official and private - is widely acknowledged to be affected by silences and elisions, euphemisms and denials. ${ }^{10}$ As a result, archaeologists have emphasised the need for multiple lines of evidence to better understand the intertwined elements of frontier encounter. In particular they advocate the use of a landscape perspective to provide a broader geographic scale at which to examine the various strands of conflict, including those identified through primary and secondary historical sources, oral sources, anthropology and archaeology. ${ }^{11}$ Part of a wider scholarly movement to map less conventional and more qualitative forms of data, ${ }^{12}$ such research explores ways to visualise sociospatial processes. In other words, rather than focussing on the details of individual sites, landscape approaches favour integrating quantitative and qualitative data at a regional scale to provide a better understanding of how lived experience in the past may have related to place and how particular behaviours might emerge in specific geographical circumstances. ${ }^{13}$ Far more than just 'telling stories with maps', it has encouraged the asking of more spatially sensitive questions and provides an alternative means to understand choices, actions and reactions that might not have been made explicit at the time.

The narrative mapping work in this paper derives from a collaborative project between archaeologists and the River Murray and Mallee Aboriginal Corporation (RMMAC) to investigate Aboriginal-European relations on Calperum Station, near Renmark, on the western Central Murray (Figure 1). Since it is not possible to understand the Aboriginal landscape of the historical period at Calperum without reference to the events that surrounded it, this paper presents an analysis of early contact in the wider region between 1830

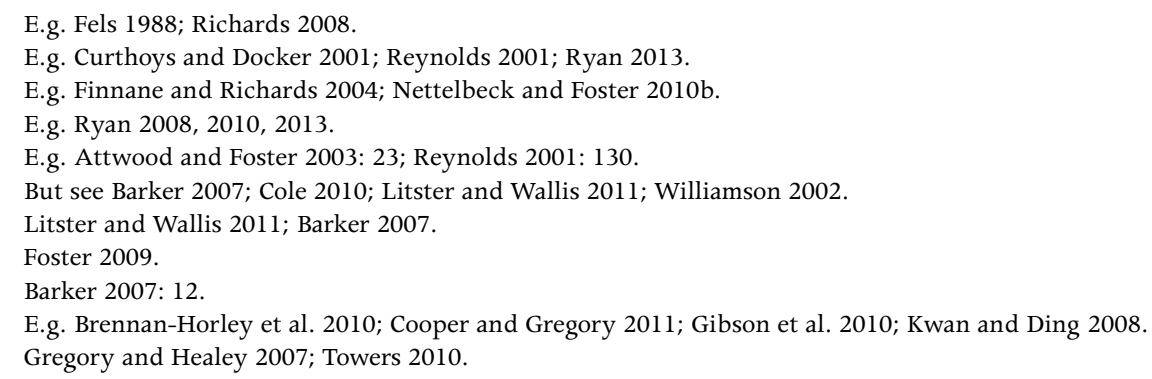


and 1841. Specifically, it sets out to reassemble the patterns of often violent engagement that occurred between Aboriginal and European people along the Overland Stock Route as these can be reconstructed from primary and secondary sources. In seeking to map the location of these encounters we have drawn on the accounts of explorers and overlanders, police and volunteer police parties and later overland travellers. ${ }^{14}$ Official reports from the Police Commissioner and the Protector of Aborigines, the Protector's correspondence from 1840 to 1857, and the various statements provided by members of overlanding parties as part of the Rufus River enquiry, provided further versions of events in the region.

This wealth of historical sources pertaining to the western Central Murray provides an apt context in which to revisit the pattern of violent encounter. Prior historical analyses in this region have tended to concentrate overwhelmingly on the most widely known event - the Rufus River massacre in August 1841, in which approximately 30 Aboriginal people were killed as a result of two consecutive encounters with a group of overlanders subsequently reinforced by a police party. ${ }^{15}$ Nettelbeck and Foster have analysed the Rufus River massacre from several perspectives, mainly focussed around 'the chasm between the way in which violence was reported and remembered' ${ }^{16}$ Teasing out the narrative dimensions of its subsequent literary treatments as it became transformed into a story of pioneer superiority and achievement over the course of the nineteenth and twentieth centuries allowed them to chart the ways in which 'celebratory mythologies of foundation' were constructed through the changing language of its various iterations. ${ }^{17}$

Closer to the intent of this paper is the study by Hemming, who synthesised many of the same events along the Murray from the Darling to Nor West Bend. By adopting a broad geographical scope, Hemming was able to make a number of pertinent, yet preliminary, observations about the spatial aspects of conflict, particularly the tendency of Aboriginal people to attack parties at vulnerable river crossings, and the evidence for cooperation between neighbouring groups when conducting these attacks. ${ }^{18}$

Nettelbeck's, Foster's and Hemming's focus on the Rufus River above all other places and encounters, however, has failed to capture some of the meanings attributed to other places in the landscape where conflict occurred, in the process

\footnotetext{
14 For explorers and overlanders, see Bonney n.d.; Buchanan 1923; Crawford 1839; Eyre 1845, 1984; Hawdon 1952, 1952; Sturt 1833, 1838, 1849; Webster 1987. For police and volunteer parties, see Hawker 1841-45; O'Halloran 184la,b, 1904. Other police recollections, such as Tolmer's 1882 and McLean's 1903 memoirs, provided only general information or repeated information from other sources. Unfortunately, Buchanan's original diary is missing from the State Library of South Australia.

15 Hemming 1984; Nettelbeck 1999; Nettelbeck and Foster 2010a.

16 Foster 2009: 68.1.

17 Nettelbeck 1999: 82. See also Foster 2009; Foster and Nettelbeck 2012; Foster et al. 2001.

18 Hemming 1984: 13-15.
} 
rendering them less visible and meaningful. It has also emphasised the experience of the Maraura and downplayed the effects on the other Aboriginal groups that existed along this section of the river. ${ }^{19}$ This gap is perhaps understandable, as neither Nettelbeck and Foster nor Hemming were interested in capturing the spatial dimensions of encounter other than in a very general way, and also relied on a more curtailed collection of primary sources. In this paper we have consulted a wider range of contemporary accounts, including both Charles Sturt's and James Coutts Crawford's original journals relating to their overland journeys and the portion of Thomas O'Halloran's diary covering his two expeditions to Lake Victoria that was not deposited with State Records of South Australia. ${ }^{20}$ Coutts Crawford's journal, in particular, varies considerably from the two later published versions of it, and specifically in terms of encounters with Aboriginal people. ${ }^{21}$ Many of these narratives provided geographic locations for events at various levels of specificity, most notably $\mathrm{O}^{\prime}$ Halloran's military notations of distances between camps and major landmarks, James Hawker's and James Coutts Crawford's estimates of directions and distances travelled and Sturt's original, hand-drawn charts accompanying his 1830 journey along the river. Historical maps and newspaper articles were used to assist in the more precise identification of overlander travel routes, significant landmarks and the specifics of particular encounters.

The impetus for this paper derives from anthropological observations made at the time of the First Peoples of the River Murray and Mallee Region Native Title Claim, for which extensive genealogies were compiled. As part of this process it became clear that the current RMMAC membership could trace its descent from only approximately 30 individuals (the apical ancestors). ${ }^{22}$ This number is in stark contrast to the population estimates in observations from the 1840s that refer to hundreds of people at some locales, particularly those

19 For the purposes of this paper we have adopted Tindale's (1974) narrower group 'boundaries' and names, although we do not claim that his interpretations are without issue (e.g. a detailed analysis would involve an exegesis of the various ethnohistorical accounts and syntheses provided by Berndt et al. 1993; Curr 1886; Eyre 1845; Horton 1994; Howitt 1904; Radcliffe-Brown 1918; Richards 1903; Smyth 1878; Taplin 1879 and Tindale 1940, among others). Unlike in other areas of Australia, however, Tindale did conduct primary research with 'informants' in the area of the broader native title claim (e.g. Robert [Tarby] Mason, Peter Boney and Frank Fletcher) for this region (Turner $v$ State of South Australia [2011] FCA 131218 November 2011).

20 The portion of O'Halloran's diary (184la) held by State Records of South Australia (SRSA GRG 5/81) covers the period from 22 April to 5 May and 23 June to 8 July 1841. The 'missing' portion (1841b) covers events between 31 May and 22 June 1841 and has only recently been rediscovered. This portion is held by the South Australian Police Historical Society.

21 Crawford 1880; Pike 1965.

22 See Turner $v$ State of South Australia. The South Australian portion of the western Central Murray was formerly covered by the native title claim known as 'First Peoples of the River Murray and Mallee Region', which resulted in the determination (by consent) that native title exists in certain parcels of land within the original claim; see native title determination application no. SAD 6026 of 1998. Native title rights and interests from this decision are held in trust by RMMAC. 
with more reliable water and other resources. ${ }^{23}$ Further, none of the named Indigenous people who appeared in the early ethnohistorical accounts could be matched to these known apical ancestors, suggesting that - for whatever reason - they left no known descendants. In the context of discussions concerning conflict and the effects of colonisation, this is a sobering figure and one that flagged the necessity of investigating the contact history of the region in greater detail. The 1830s and early 1840s were crucial years for the development of contemporary and subsequent relationships between European and Aboriginal people in this area and affected population numbers and settlement patterns for decades to come.

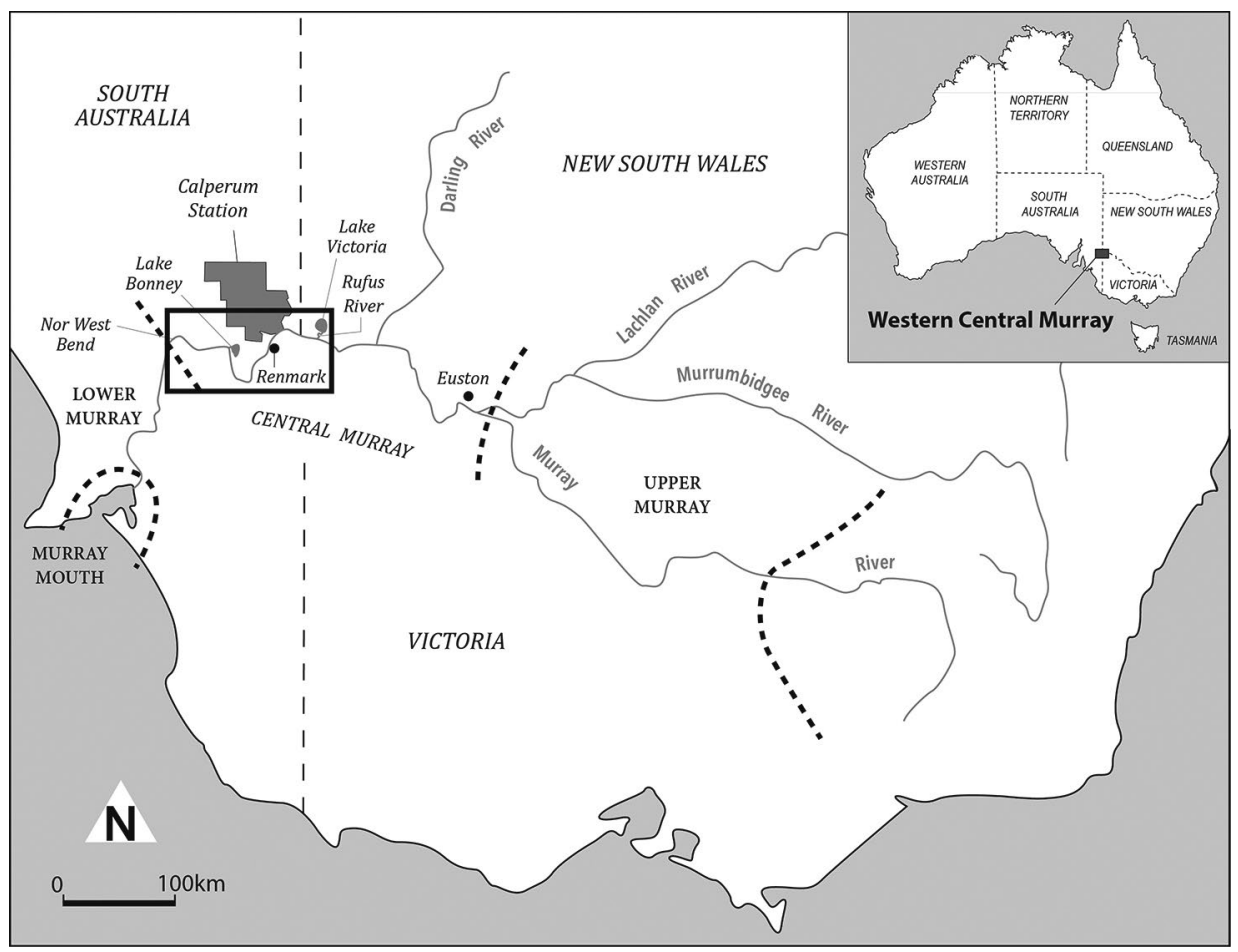

Figure 1: Location of the western Central Murray study area.

Source: Map created by authors. Murray River divisions are from Littleton 1998: 2.

By adopting an explicit landscape perspective on the nature and scale of violence across the western Central Murray we have been able to document the nuances of engagement in greater detail, making it clear that frontier violence in this space was both more sustained and highly complex than has previously been considered. We argue here that spatially visualising the narratives of conflict contained in primary and secondary historical accounts for a single region 
provides a better perspective from which to examine the more subtle ebbs and flows of action and response that occurred as a result of contact. Anchoring multiple historical sources to specific spaces highlights places of safety and danger in the landscape, reveals new perspectives on the use of European objects by Aboriginal people in the region in 'conciliatory' and 'retaliatory' ways, and allows some of the repercussions of this sequence of events to be unfolded across space and time.

\section{Contact and conflict along the western Central Murray}

\section{The beginning: Early contacts 1830-40}

It is likely that the first physical contact between Aboriginal peoples and Europeans on the western Central Murray took place when Charles Sturt travelled down the river in $1830 .{ }^{24}$ Although frequently glossed as 'friendly', even these initial encounters were precarious. While Sturt reported no overt hostility, he was certainly armed for it and alert to its possibility, only narrowly escaping it at several points between the Rufus River and Nor West Bend. ${ }^{25}$ Sturt's anxiety was exacerbated by the repeated and intense interest shown in his party and their possessions and by Aboriginal people's indifference to his demonstrations of European gunfire. At the Lindesay (now Lindsay) River junction Sturt found one group to be so 'troublesome' that he thought a 'quarrel' might result.

No other Europeans are recorded travelling through the region until the Overland Stock Route opened between Sydney and Adelaide in 1838. The first 'overlanders' to make the trek were Joseph Hawdon and Charles Bonney in April, bringing 335 cattle for the Adelaide market. Like Sturt, each man in Hawdon's and Bonney's party went armed, in their case 'with a carabine, a pair of pistols, and a bayonet', although this was as much for defence against bushrangers as anything else. ${ }^{26}$ The party encountered one 'troublesome' Aboriginal group three days before reaching the Murray and Rufus River junction ${ }^{27}$ and minor occurrences of attempted theft and cattle spearing between the Rufus and Nor West Bend. ${ }^{28}$

\footnotetext{
24 Sturt 1833. Sturt was, however, preceded by the effects of European invasion via evidence of the spread of introduced diseases.

25 Sturt 1833: 138-39, 191-95.

26 Hawdon 1952: 3.

27 Hawdon 1952: 40.

28 Hawdon 1952: 40-49.
} 
Hawdon and Bonney were closely followed by Edward Eyre in June and Sturt in August 1838, both of whom travelled overland with cattle. Eyre came through again in March 1839 with 1,000 sheep and found people to be 'for the most part tractable and friendly', 29 although he still kept his party's arms within easy reach. In June, west of the Rufus River he encountered 'a numerous and very troublesome' group, who, after a stand-off on the previous evening, returned at dawn. A second stand-off then ensued, prompting Eyre and his party to defend their drays:

The time passed slowly and anxiously for about two hours, the natives still keeping their position ... When the teams were yoked and all ready to move I went, alone and unarmed, to the assembled natives and distributed pieces of iron hoop cut and sharpened so as to make chisels and other little gifts. They seemed greatly pleased with the presents, gave a tremendous shout and we were all very good friends again ... I believe, however, that under God's mercy we had escaped a most imminent peril and that had there been the least fear or indecision shewn the whole party would certainly have been murdered. ${ }^{30}$

Eyre, like Sturt and Hawdon before him, was observing the signs of incipient conflict, which quickly came to a head over the following three years. Based largely on newspaper reports and advertisements noting the arrival of overland parties and their stock for the Adelaide market, it is possible to reconstruct something of the scale of the overlanding enterprise in its first three years. Between April 1838 and April 1841 a minimum of 36 parties travelled the western Central Murray route, bringing with them at least 480 Europeans, 90,000 sheep and 15,000 cattle, as well as horses, bullocks, drays and goods into Aboriginal territories. Moreover, the stock route for which Hawdon and Bonney received the credit followed much older Aboriginal pathways (see Figure 2), a common occurrence across Australia that complicated Aboriginal people's access to traditional travel routes. ${ }^{31}$ By September 1840 - and indeed, probably much earlier - the overland route had become so distinct that it was a clearly visible road. ${ }^{32}$

\section{The end: The Rufus River massacre 1841}

On 16 April 1841 one of these overlanding parties, led by Henry Inman and consisting of 11 men and 5,000 sheep, was attacked on the banks of the river 'at a place 40 miles to the eastward of Lake Bonney'.$^{33}$ According to Governor Grey:

\footnotetext{
29 SA Gazette and Colonial Register, 21 July 1838.

30 Eyre 1984: 158.

31 Spooner et al. 2010.

32 South Australian Register, 5 September 1840. Note that some parties also travelled along the south bank of the Murray for part of the journey, see Eyre 1984: 187.

33 Deposition of Henry Inman in Great Britain, Parliament, House of Commons 1843, Papers Relative to South Australia, Aborigines (hereafter PRSAA), Enclosure 1 in No. 87: 268.
} 
[a] body of natives from 300-400 strong ... forcibly took possession of the sheep, drays \&c, and dispersed the Europeans, severely wounding two, and nearly killing another ... and this notwithstanding a strenuous resistance was offered, and at least one of the natives killed. ${ }^{34}$

This 'outrage' caused a police party to be dispatched to the area, led by the Commissioner of Police, Major Thomas O'Halloran, which was recalled before it reached its destination. In their stead a group of volunteers, including Henry Field, a member of Inman's original party, James Hawker and Field's brother, Lieutenant William George Field, offered to recover the sheep, setting out on 7 May. On 13 May they too

fell in with the same party of natives, between 300 and 400 strong, who attacked them, wounding one of their number, at the same time killing one, and wounding two, of their horses. The Aborigines eventually compelled them to a hasty retreat, although not without suffering a loss of from eight to ten men on their own part. ${ }^{35}$

The attacks on Inman's and Field's parties sparked a concerted public reaction. In order to avoid a vigilante group, and in response to the news that another overlanding party, led by Alfred Langhorne, was presently en route, newly arrived Governor Grey swore in a batch of volunteers as special constables under the jurisdiction of $\mathrm{O}^{\prime}$ Halloran and the Protector of Aborigines, Matthew Moorhouse. A large party of men, including mounted and foot police, left Adelaide on 31 May. They met up with Langhorne's party on 22 June, only to learn that they had been attacked two days earlier at the Rufus River, resulting in the deaths of four Europeans and the wounding of another two. Five Aboriginal people had been killed and approximately 10 wounded in the conflict. ${ }^{36}$

In response to a formal request in July 1841 to protect a third group of overlanders, this time led by William Robinson, another official party, including police, three Aboriginal people and Moorhouse, again left for the Murray. On arriving at the Rufus on 27 August they met up with Robinson's party, who, like Langhorne's, had been attacked further to the east on the previous day. Five Aboriginal men had been killed, and 10 wounded, but there had been no loss of European life. In the hours following, Moorhouse and two others encountered a large party of men and women near Lake Victoria, who immediately ran towards them and a second clash ensued, despite Moorhouse's attempts to negotiate through interpreters. In the ensuing gunfire 'nearly 30' Aboriginal people were killed (although at the subsequent enquiry Moorhouse acknowledged that he had only seen 21 bodies), ${ }^{37}$ 'about $10^{\prime}$ wounded and four captured. ${ }^{38}$ Of the Europeans, only Robinson himself

\footnotetext{
Grey to Russell, 29 May 1841, in PRSAA 1843, Enclosure 87: 267.

Grey to Russell, 29 May 1841, in PRSAA 1843, Enclosure 87: 267.

Moorhouse to Mundy, 4 September 1841, in PRSAA 1843, Enclosure 1 in No. 97: 294

Testimony of Matthew Moorhouse to Bench of Magistrates, 21 September 1841, in PRSAA 1843: 299.

Moorhouse to Mundy, 4 September 1841, in PRSAA 1843, Enclosure 1 in No. 97: 294.
} 
was wounded. A subsequent enquiry questioned the participants, including Pangki Pangki, the Aboriginal interpreter, and Pulkanta, one of the Rufus River captives, but eventually declared that the conduct of both European parties was justifiable. ${ }^{39}$ Much later this 'collision' became known as the Rufus River massacre. ${ }^{40}$

The Rufus River conflict is often seen as the end-point of conflict in the region, both because of its scale, since it signalled the largest number of deaths as a result of a single event, but also because reports of attacks on overlanding parties disappear from the literature after 1842. The arrival of such parties to Adelaide was no longer a novelty and only isolated accounts of travel along the route can be found into the 1850s. ${ }^{41}$ The government response was to establish a local military presence in the area, but also to try and pacify Aboriginal people by defusing social tensions and supplying them with rations. ${ }^{42}$ To accomplish this, Edward Eyre was appointed Resident Magistrate and Protector of Aborigines on the Murray and a military detachment of 12 men and a non-commissioned officer from the 96th Regiment dispatched with him to his pastoral lease, Moorundie. From here Eyre visited the Rufus River in the first half of 1842 and found the numbers of Aboriginal people much reduced, but also recommended that a rations post be established at the junction of the Rufus and the Murray. ${ }^{43}$ The military were only a temporary control measure and were replaced by civilian police at Ral Ral in 1849. The intent of this station was expressly to counter 'the ferocious disposition of the aborigines in that district, and of the marauding habit they have acquired from a long series of successful attacks upon overland parties', ${ }^{44}$ implying that at least some level of conflict may have continued throughout the 1840s.

\section{Visualising a spatial narrative of encounter 1830-41}

Having 'bookended' encounters along the western Central Murray by separating them chronologically, it is appropriate now to revisit these narratives and question them spatially. Plotting the distribution of events between 1830 and 1841 reveals numerous locations where actual or potential conflict took place and five 'hot spots' where repeated evidence of conflict occurred (Figure 2). ${ }^{45}$ The most well

\footnotetext{
39 Bench of Magistrates, Minutes of meeting 20-22 September 1841, in PRSAA 1843, Enclosure in No. $98: 302$.

40 See Foster 2009; Foster and Nettelbeck 2010; Foster et al. 2001.

41 E.g. Gerstäcker 1853: 454-56; Observer, 7 April 1923.

42 Foster 1989.

43 Eyre to Mundy, 10 January 1842, in PRSAA 1843, Enclosure in No. 101: 305-6.

44 South Australian Register, 18 August 1849: 4.

45 We define conflict as any event that caused friction between Aboriginal and European people, regardless of whether or not it ended in actual violence.
} 
known of these is 'Langhorne's Ferry', where teams crossed the Rufus, since this was the site of the Rufus River massacre, as well as at least four previous violent encounters. Four other locations are also apparent, however, which have received comparatively less attention in the literature: 'Dead Man's Flat', west of Lake Bonney; 'Tolmer's Flat' east of Lake Bonney; 'Bluebeard's Den' near Ral Ral; and the 'Hornet's Nest', just inside the present boundary of South Australia.

\section{Dead Man's Flat}

In October 1839, George McLeod and Robert Flood were travelling east along the Central Murray with provisions for John Finnis's overlanding party. Overtaking Lachlan Mackinnon's party travelling west towards Adelaide, they soon learnt that Thomas Young, Mackinnon's overseer, had been killed about seven miles further to the east several days before. McLeod and Flood were themselves attacked the following morning in the same vicinity. ${ }^{46}$ The circumstances leading up to, and following, Young's death were not mentioned by McLeod or the single published newspaper report, ${ }^{47}$ and, for his part, Mackinnon merely remarked for the newspapers that ' $\mathrm{t}]$ he natives were very friendly and peaceable'. ${ }^{48}$ The South Australian Register was subsequently given a description of Young's death which noted that, 'It is not known that any offence was given by the party to the natives to incite them to commit such a cold-blooded murder' ${ }^{49}$ but which also omitted any reference to Mackinnon's party's reaction. In the following month at least two further encounters took place in this vicinity, including attacks on the provisioning drays travelling to meet Alexander Buchanan's party in November $1839^{50}$ and on Nelson Tooth's party in December. In February 1841, Edward, John and Ephraim Howe's party thought they were being followed from this flat ${ }^{51}$ and when $\mathrm{O}^{\prime}$ Halloran reached the location in April 1841, he described it as:

a spot where several parties have been attacked (Mr Eyre, ${ }^{52}$ Tooth $\&$ others) and where a European was killed by the natives and lies buried between 2 trees with an F upon one, this man belonged to Mr McKinnon's party - I shall therefore distinguish our present encampment as the 'Dead Man's flat' ... From what I can gather from some of the men who came overland - several natives have been killed upon different occasions - I understand the latter nearly took the life of Mr Tooth and Eyre was turned back and obliged to get further strength ere he could pass. ${ }^{53}$

\footnotetext{
46 South Australian Register, 16 November 1839.

47 South Australian Register, 30 November 1839.

48 South Australian Register, 26 October 1839.

49 South Australian Register 30 November 1839.

50 Buchanan 1923: 75.

51 Webster 1987: 210.

52 This is not mentioned by Eyre.

53 O'Halloran Diary 28 April 1841a.
} 


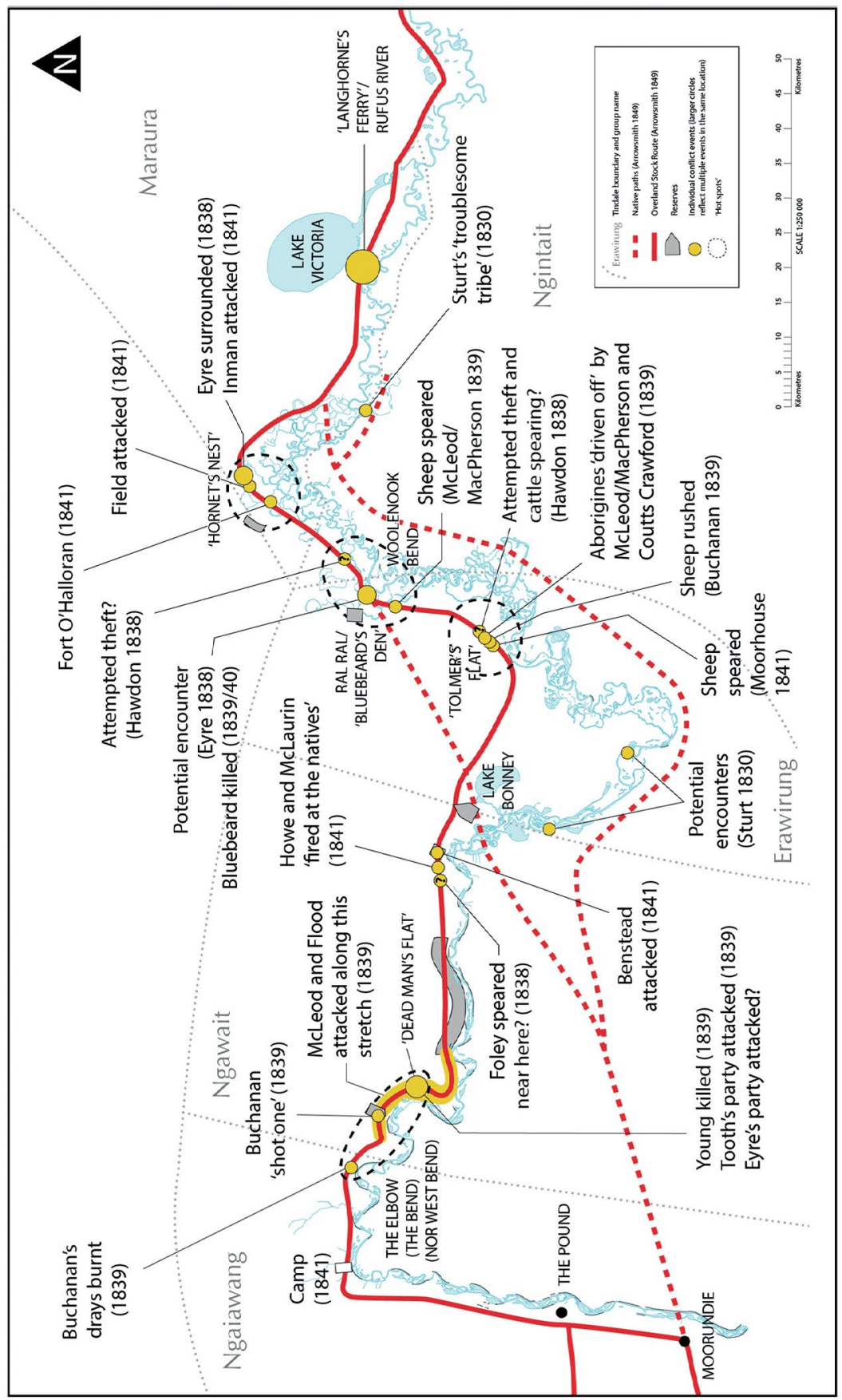

Figure 2: Conflict locations and events along the western Central Murray, showing Tindale's boundaries. Spatial locations for these events were crossreferenced between multiple sources wherever possible, although some locations could only be mapped with a great degree of spatial uncertainty (indicated by '?'). 
The Aboriginal side of these events is unknown, but the attack on McLeod and Flood and both of the November attacks could well have been reprisal raids for earlier deaths caused by Mackinnon's party. Alexander Buchanan took no chances himself in November, since, not long after passing through Dead Man's Flat, he noted that he had seen 'a good many blacks opposite bank of the river, fired upon them and killed one, the rest made off immediately' ${ }^{54}$

\section{Tolmer's Flat}

In this area Hawdon noted an attempted theft by the 'principal man' from a group of 90 Aboriginal people who had gathered near his camp, ${ }^{55}$ and several attempts were made on stock, including that owned by Hawdon, Buchanan and the second police party. ${ }^{56}$ Here also the combined parties of George McLeod, Huntly MacPherson and James Coutts Crawford 'drove off' a 'great mob' of about 50 people in April 1839 after several other encounters since the Rufus. ${ }^{57}$

\section{Ral Ral and Bluebeard's Den}

This was the area for various events (see Figure 2), including another attempted theft from Hawdon's camp and one of Eyre's near collisions in $1838 .{ }^{58}$ In 1839 Aboriginal people speared 11 or 12 of McLeod's and MacPherson's sheep, resulting in Coutts Crawford's cryptic phrase: 'Had some diver[?] shooting. ${ }^{59}$ It was also the location of Bluebeard's Den. This was the name given by $\mathrm{O}^{\prime}$ Halloran to a place on Woolenook Bend where a well-known Aboriginal man, variously referred to as 'Old Bluebeard' by Buchanan, ${ }^{60}$ or 'Greybeard' by Eyre, ${ }^{61}$ was killed by Charles Miller in December 1839 or January 1840:

Monday 27th June ... We are now encamped where the famous 'Blue Beard' mentioned in Sturts [sic] book, was shot some eighteen mths ago - He was a very old man with a long white beard; \& tis said was shot ['by Miller' crossed out] when in the act of some treachery towards Millers party - I shall call this Blue Beards Den. ${ }^{62}$

\footnotetext{
54 Buchanan 1923: 75. Buchanan's memoirs contain several asides in which violence towards Aboriginal people, including murder, was committed quite casually, see, for example, Buchanan 1923: 75.

55 Hawdon 1952: 48-49.

56 Moorhouse to Mundy, 4 September 1841, in PRSAA 1843, Enclosure 1 in No. 97: 294.

57 Coutts Crawford Diary 4 April 1839 (Papers M600, M687-688, National Library of Australia).

58 Hawdon 1952: 47; Eyre 1984: 159.

59 Coutts Crawford Diary 3 April 1839. This is literally all Coutts Crawford has to say about the event, and no number of casualties is recorded.

60 Buchanan 1923: 74.

61 Eyre 1984: 158; see also Sturt 1833: 230-34.

62 O'Halloran Diary 27 June 184la.
} 
Sturt had originally met Greybeard in 1830 when he was guided by him along part of the western Central Murray. He encountered him again on his second journey overland in 1838 as an old friend. ${ }^{63}$ Eyre felt similarly, ${ }^{64}$ although Buchanan summarily dismissed him as '[a] noted chief and a great thief' ${ }^{65}$ Sturt further noted:

Here, or near this spot also, the old white-headed native, who used to attend the overland parties, was shot by Miller, a discharged soldier, I am sorry to say, of my own regiment ... He was shot by Miller in cold blood, whilst talking to one of the men of the party of which unfortunately he had the charge; but retribution soon followed. Miller was shortly afterwards severely wounded by the natives. ${ }^{66}$

\section{The Hornet's Nest}

The vicinity of the Hornet's Nest was the focus for several violent encounters, including the attacks on Inman's overlanding party in April 1841 and on Field's volunteer party in May. Although Inman had noted that 'one native only was observed by the party to fall', ${ }^{67}$ Field's party recorded eight Aboriginal deaths, a statement that was generally borne out by Moorhouse's interview of Aboriginal people at Dead Man's Flat in the following month:

They had heard from other natives that an attack had been made upon Europeans; That the natives had taken a large quantity of sheep, provisions \& clothing; That one native was shot dead at the time and at a subsequent time, several others were shot by a party on horseback. ${ }^{68}$

When $\mathrm{O}^{\prime}$ Halloran arrived at the area in June 1841 he felt himself 'in the very nest of the hornets', and so named his fortified camp the Hornet's Nest. ${ }^{69}$

\section{Langhorne's Ferry/Rufus River}

The first recorded encounters in this vicinity took place in March 1839 and involved the combined parties of Coutts Crawford and McLeod and MacPherson, who were attacked by a large group of Aboriginal people at sunset:

\footnotetext{
63 Sturt Diary 5 August 1838 (SRSA GRG 5/81).

64 Eyre 1984: 157, 187.

65 Buchanan 1923: 74.

66 Sturt 1849: 86-87.

67 Deposition of Henry Inman in PRSAA 1843, Enclosure 1 in No. 87: 268.

68 Moorhouse to Mundy, 30 June 1841, Protector's Letterbooks 1840-1857, SRSA GRG 52/7.

69 O'Halloran Diary 217 June 184la; see also Tolmer 1882: 232. It was jokingly referred to as Fort O'Halloran by others in the police party and the location was later plotted by Arrowsmith as Fort O'Halloran on his 1849 map of 'Captn. Sturt's route from Adelaide into the Centre of Australia'.
} 
Wednesday March $28^{\text {th }}$

The cattle ... were going into the point when a number of blacks came up at the head with their spears. Riley who was ahead ran for it. They chased him up to the drays where the men gave them a volley and drove them across the river. Took 4 spears ...

Thursday March $29^{\text {th }}$

Rose at daybreak - the stockmen on going to count the cattle, found our black friends of the night before all collected, to the number of 50 or 60 , with their spears among the cattle with some difficulty they drove them across the river. Took 6 spears, a nullah nullah and some sharpening stones ... Passed on over a flat alluvial land with a sand bank on our right ... MacPherson \& myself were on ahead on the sand bank when we heard a sound of firing behind us and on returning that another engagement had taken place with the same blacks several of whom had at last got a good peppering with small shot. Took several spears. ${ }^{70}$

According to Pike this encounter took place at the Rufus, but Coutts Crawford's calculations of distance from the Darling puts the parties slightly further to the west, so this event is likely to have taken place between the Rufus and Calperum Station. ${ }^{71}$ Moorhouse noted two further incidents at the Rufus later that year, although without naming either party:

Nineteen months ago [i.e. around December 1839], the drays of a cattle party were attempted to be taken at this very place by a group of Natives. Ten men on horseback all supplied with firearms were on the banks of the River at the time, and repelled the Natives at once by firing upon them. The Natives retreated as soon as they saw one or two of their tribe shot, but they were followed for about 15 miles by those on horseback \& Firing kept up the whole time. Thirteen months ago [i.e. around June 1840] a similar encounter took place on the same spot $\&$ the natives routed with great loss. ${ }^{72}$

Langhorne's party of 16 were attacked at the same location in June 1841, leading to the deaths of four Europeans, the wounding of two others, and the deaths of five Aboriginal people. ${ }^{73}$ One of the Europeans who was wounded here was the same Charles Miller who had travelled the route at least three times and who

70 Coutts Crawford Diary 28 and 29 March 1839. Pike's published version of this entry has very little in common with the original (see Pike 1965: 8) and contains considerable embellishment, including details of the encounter with Inman's party that occurred at the Rufus two years later.

71 Pike 1965: 8.

72 Moorhouse to Mundy, 12 July 1841, Protector's Letterbooks 1840-1857, SRSA GRG 52/7. Several overland parties moved through at these times, including, in December 1839, Charles Miller, Edward and John Howe, Cameron and Lewis Huon, and, in June 1840, William Spence Peter.

73 Moorhouse to Mundy, 30 June 1841, Protector's Letterbooks 1840-1857, SRSA GRG 52/7. 
had been responsible for Bluebeard's death 18 months earlier. Miller was one of those to have noted the change in Aboriginal people's attitudes to overlanding parties, although without mentioning his own role:

Mr Millar [sic] ... said this is the third time I have come overland from Sydney; the first time I came the natives were of great assistance to my party; they helped us to drive our cattle for many miles; they did not attempt to steal or take anything from us. The second time they were more bold; they would pilfer and steal from our encampment and in the night they several times crossed the Murray and speared the sheep so that the shepherds were obliged to fire upon them. I never saw them to offer to attack the drays before the present time. ${ }^{74}$

By the time Robinson's party reached the crossing in August 1841 they were well aware of earlier encounters and had combined with another overlanding party to present a force of 27 well-armed men. ${ }^{75}$

The number of deaths across all of these encounters is unknown, but the fragmentary glimpses in primary sources suggest that at least 42 Aboriginal people were killed and 34 wounded. In comparison, only five Europeans are known to have been killed and 12 wounded (Table 1). In 1842, as part of his initial journeys into the region after the Rufus River massacre, Eyre recorded the only Aboriginal perspectives on this period, which clearly emphasised the casual aggression of overlanding parties:

The natives themselves have lately brought under my notice instances in which they describe the conduct of some of the parties ... as having been barbarous and revolting in the extreme. I have no reason to doubt the statements that have been made to me; on the contrary, my impression is, that they are but too true. I have found the accounts given at different times always the same, and where more than one has been received, they have been consistent with each other. I have myself seen the scars of the wounds said to have been inflicted on these occasions, and I do firmly believe the assertion made by the natives 'that, in many instances, they have been most wantonly fired at by Europeans, as soon as they have been seen, without the slightest previous provocation given upon their part, at points of the river where no disturbances have occurred with the natives, and in instances where the number (sometimes not exceeding two) could not afford even the shallow excuse of a dread of numbers' ${ }^{76}$

The Aboriginal statements given to Eyre and the genealogical work associated with the First Peoples of the River Murray and Mallee Region Native Title Claim would suggest that the numbers of unrecorded deaths on the Aboriginal side of the equation were far higher, although when and how this happened is not yet known.

74 Moorhouse to Mundy, 12 July 1841, Protector's Letterbooks 1840-1857, SRSA GRG 52/7.

75 Southern Australian, 9 July 1841.

76 Southern Australian, 10 June 1842. 


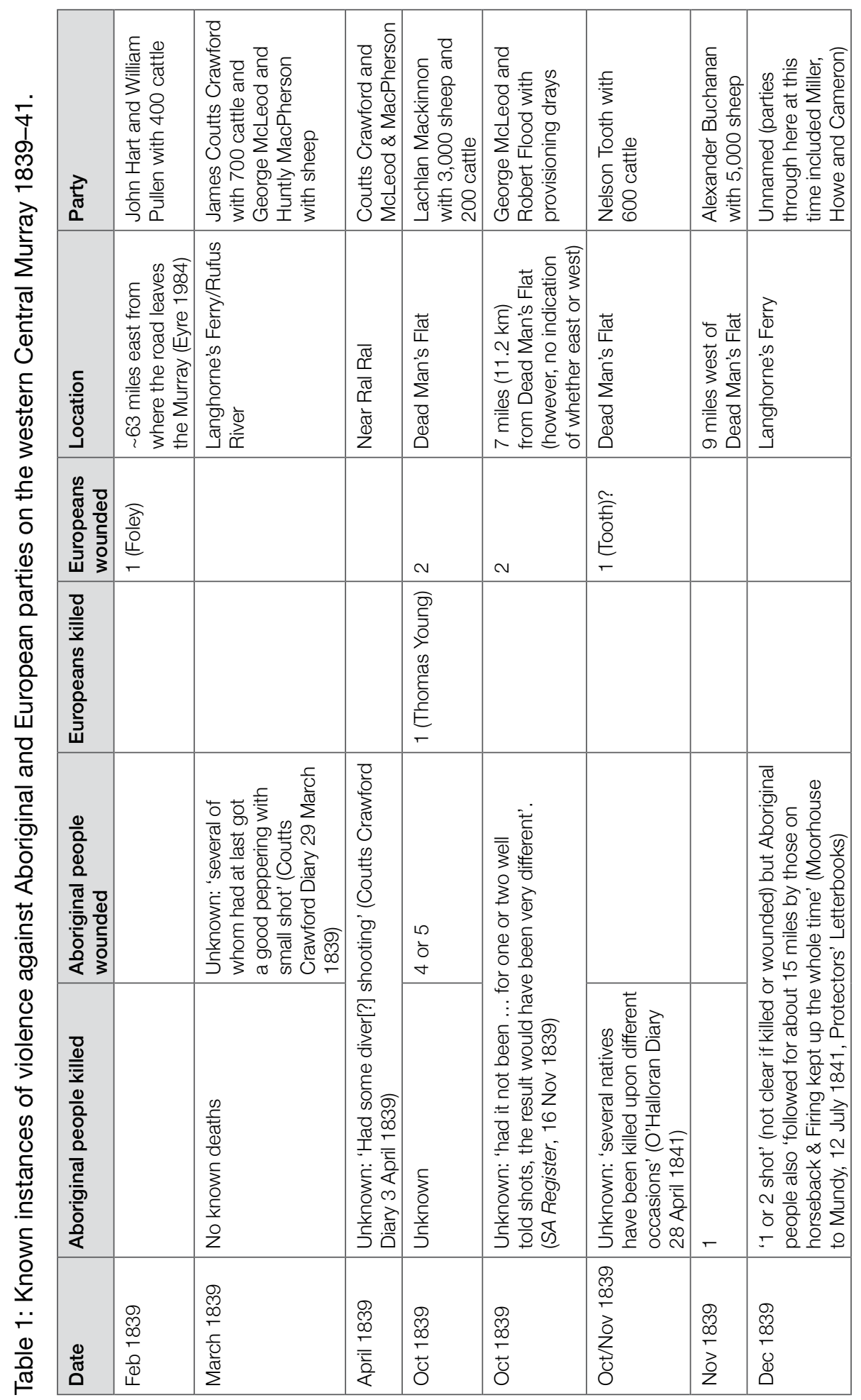


THE SPACE OF CONFLICT

\begin{tabular}{|c|c|c|c|c|c|c|c|c|c|}
\hline $\begin{array}{c}\vec{E} \\
\frac{\vec{E}}{0} \\
0\end{array}$ & 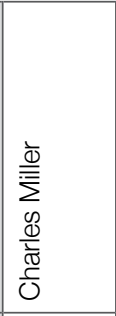 & 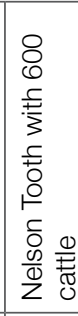 & 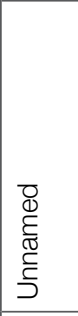 & 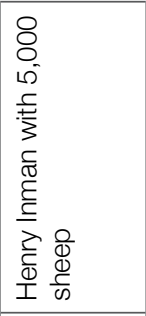 & 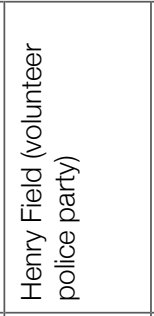 & 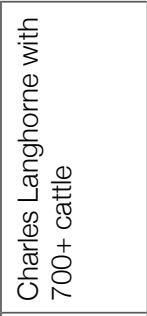 & 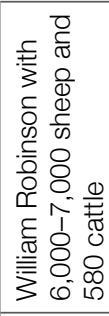 & 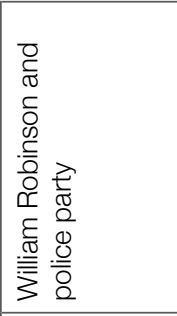 & \\
\hline 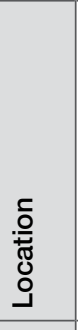 & 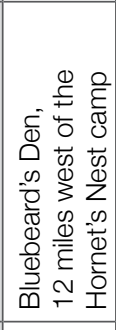 & 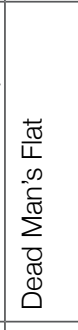 & 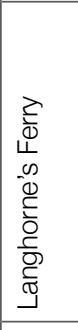 & 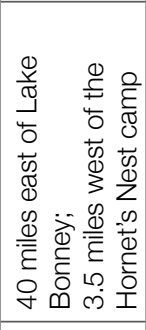 & 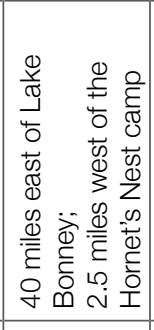 & 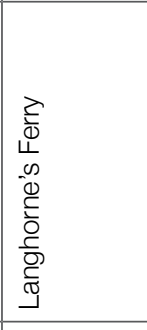 & 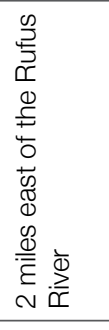 & 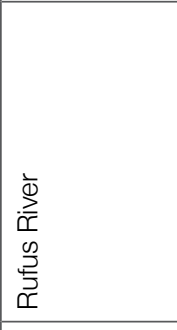 & \\
\hline 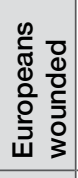 & & 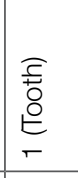 & & m & 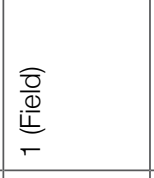 & 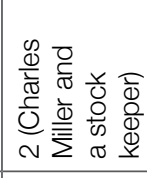 & & 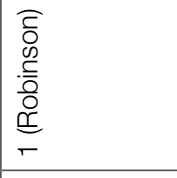 & $\cong$ \\
\hline 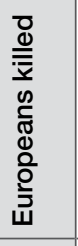 & & & & & & 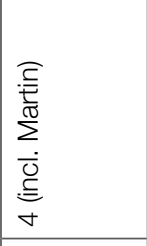 & & 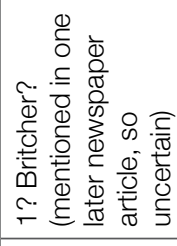 & \llcorner \\
\hline $\begin{array}{l}\frac{0}{0} \\
\frac{0}{0} \\
\frac{0}{0} \\
\frac{0}{0} \\
\frac{0}{0} \\
\frac{0}{0} \\
\frac{0}{0} \\
\frac{0}{4} \\
\frac{1}{3}\end{array}$ & & & 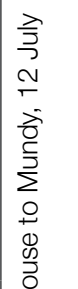 & & 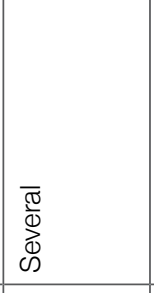 & 우 & $\stackrel{ }{\circ}$ & 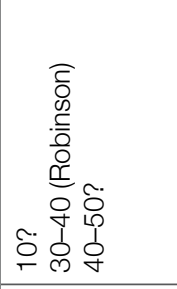 & मे \\
\hline $\begin{array}{l}\frac{\overline{0}}{0} \\
\overline{\bar{z}} \\
\frac{0}{0} \\
\frac{0}{0} \\
\frac{0}{0} \\
\frac{0}{0} \\
\frac{0}{0} \\
\frac{0}{0} \\
\frac{0}{\alpha}\end{array}$ & 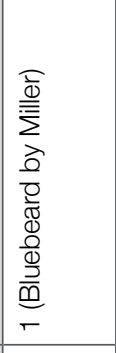 & & 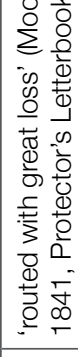 & 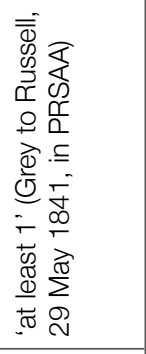 & $\infty$ & 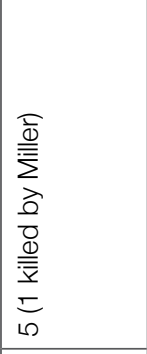 & 10 & 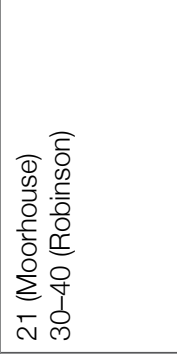 & F \\
\hline هٓ & 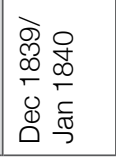 & $\begin{array}{l}\mathscr{D} \\
\infty \\
0 \\
0 \\
\mathbb{D} \\
0\end{array}$ & 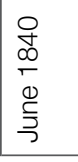 & $\begin{array}{l}\bar{c} \\
\frac{\bar{\alpha}}{0} \\
\overline{\bar{z}} \\
\overline{\frac{\alpha}{4}}\end{array}$ & 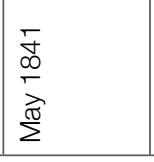 & 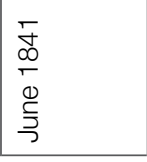 & 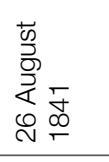 & 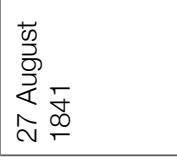 & 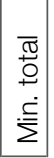 \\
\hline
\end{tabular}




\section{The toponymy and topography of violence}

In a recent study of the Great Warriors Path (the 'warpath') in the United States, Snead urged a reconsideration of the role of travel routes as meaningful places in their own right. ${ }^{77}$ Considering a travel path as a 'landscape of movement' emphasises a process of engagement with environment, topography and space that connects the experience of travel to wider cultural understandings on the part of those who use a route and it creates particular legacies around layers of previous experiences. ${ }^{78}$ The 'layers' of the Overland Stock Route were similarly constructed from the history of engagements between Aboriginal and European people, as well as the histories of particular overlanders who travelled the route more than once, such that successive groups were no doubt well aware of previous encounters, their nature, location and consequences.

O'Halloran's naming of many of the hot spots along the route framed the European perspective on the perceived dangers of this landscape, partly as a cautionary tale, but also to formalise a history for an area that was regarded as notably 'troublesome' ${ }^{79}$ For Europeans like $\mathrm{O}^{\prime}$ Halloran the area of greatest threat began immediately east of Lake Bonney: 'Crossed Lake Bonney and got to the N. side of the lake, and upon a ridge of scrub the commencement of the country of the hostile tribe at 11 a.m.' ${ }^{80}$ To Moorhouse the Aboriginal guides named this country Mettilittila Yarta - 'Thief Land' - pronouncing the inhabitants 'notorious thieves' ${ }^{81}$ It is not clear why Moorhouse and O'Halloran regarded the area west of Lake Bonney as less dangerous, however, given that some of the earliest encounters occurred here and in the space of three months (October-December 1839) one European and at least one Aboriginal person were killed (although probably many more) and other attacks made on people, livestock and property (see Figure 2).

Foster, Hosking and Nettelbeck have noted the ways in which the events leading up to the Rufus River massacre were transformed by later histories into ideological narratives of Empire and a triumph of civilisation over savagery. ${ }^{82}$ Many such accounts exploited a recurring motif of Aboriginal treachery that Foster et al. argue served to deflect responsibility for the violence away 'from the Europeans who pulled the triggers [and on] to the Maraura themselves' ${ }^{83} \mathrm{O}^{\prime}$ Halloran's toponymy accomplished a similar feat in that it highlighted a tension-filled 
conception of space, but also transformed that space into a series of discrete places with known histories of violence against Europeans. Even the naming of Bluebeard's Den, nominally an acknowledgement of a major Aboriginal death, was transformed into an 'act of some treachery' against Europeans, the choice of the term 'Den' implying some element of criminality or vice on Greybeard's part. The location of Dead Man's Flat has since been memorialised with a plaque by the National Trust, elevating one European death over all others as the sole marker of conflict events along the Overland Stock Route. ${ }^{84}$

The only Aboriginal perspectives on these events are the fragments that are contained in, and constrained by, European records. As a traditional travel pathway, Aboriginal people would have been well aware of the topographical nuances of the Overland Stock Route, although the meanings they attributed to particular spaces are not a focus of this paper. Places of durable memory were no doubt constructed from the physical remains of former encounters certainly Inman's and Field's engagements both left traces that were visible for some time. O'Halloran, for example, noted on his arrival at the Hornet's Nest that 'the whole of the sheep had long before been slaughtered, as we saw their carcasses and bones thrown about in vast heaps in various places, where the blacks had formed large encampments' ${ }^{\prime}{ }^{85}$ and Hawker noted that the flat was still strewn with bones five years later. ${ }^{86} \mathrm{O}^{\prime}$ Halloran also described a recent Aboriginal burial mound near the Hornet's Nest camp:

We came ... to a grave recently formed and very tastefully covered round with boughs in the shape of a dome, and where many blacks are buried. Our Adelaide native said that they were the bodies of those killed by Field's party. This grave lies about 100 yards from the river. ${ }^{87}$

At the Rufus a large burial mound similarly marked the site of previous conflict, as pointed out to Sturt and Eyre in 1844: 'The natives who accompanied us ... informed us that thirty of their relatives laid underneath; but they did not seem to entertain any feelings of revenge for the loss they had sustained. ${ }^{\prime 88}$

84 Part of the plaque reads, 'In retaliation, the party reportedly killed eleven Aborigines that day ...'. This figure seems to be local oral tradition and is not referred to in any contemporary accounts; see Joseph Kingsley Mack notes and clippings, SLSA PRG 1470, State Library of South Australia.

85 O'Halloran, Report of the Commissioner of Police, 27 June 1841, in PRSAA 1843, Enclosure 1 in No. 92: 278.

86 Hawker Diary 16 July 1846 (Borrow Collection, Flinders University).

87 O'Halloran 1904: 86.

88 Sturt 1849: 93. 


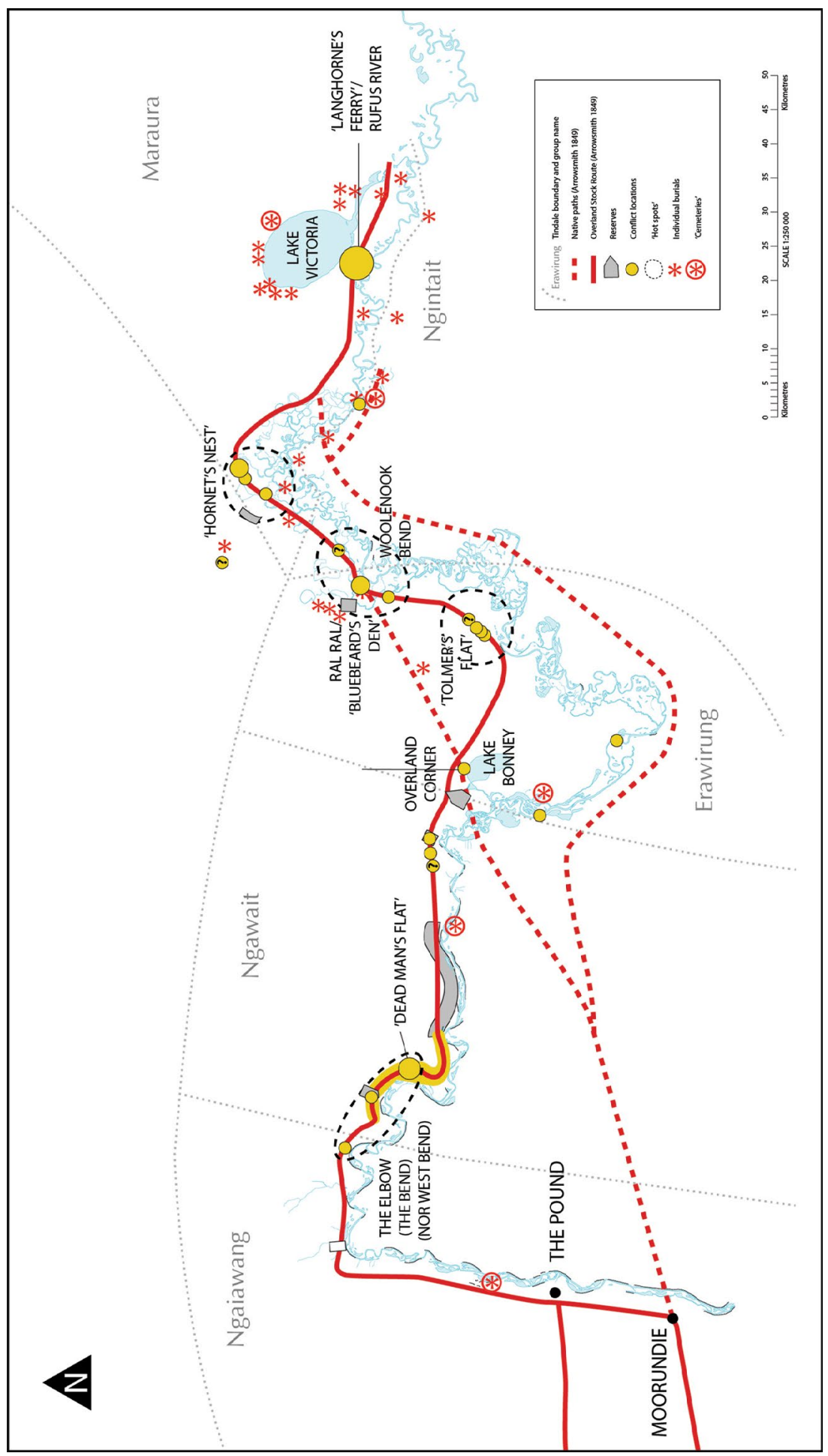

Figure 3: Conflict locations mapped against burial locations. 
Nettelbeck has suggested that at least part of the violence may have derived from the Maraura protecting such cemetery sites, ${ }^{89}$ but this is not substantiated by our plotting of the data, since smaller and larger concentrations of burials ${ }^{90}$ are distributed throughout the region (Figure 3). Furthermore, Aboriginal people's attitudes to burial sites seem to be at least partly determined by the age of the interments. Recent research at the Gillman Mound on the Adelaide Plains, for example, has suggested that periods of burial (usually associated with avoidance) and occupation (obviously associated with ongoing engagement) at sites were often temporally separated, even though, to some extent, people remained aware of the presence of the long dead within their camping places. ${ }^{91}$ This suggests complex sets of attitudes towards burial locations that do not help to connect them directly to the patterning of conflict.

More direct patterning is discernible in the physical locations for attacks, however, that were often highly sensitive to the nuances of topography. Figure 2 shows that many attacks occurred at points that considerably slowed the progress of European parties, such as steep inclines (Dead Man's Flat), river crossings ${ }^{92}$ (Langhorne's Ferry), and camping places where stock and goods had to be protected overnight (Tolmer's Flat). The attacks on Field and Inman near the Hornet's Nest took place in the area dubbed 'The Islands' by Sturt - a tangled landscape of lagoons, creeks and thick scrub that gave great advantage to Aboriginal people. ${ }^{93}$ Even more effectively, by 1841 attacks at these topographic 'bottle necks' were being enhanced by the use of highly practical tactics. Several members of Inman's and Hawker's, Langhorne's and Robinson's parties all described a similar pattern of engagement in the eastern extremity of the study area by which Aboriginal people formed themselves into a semicircle before attacking, allowing them to flank the European party and their stock. John Allan, for example, observed that '[t]he natives attacked ... in the form of a crescent, and on the party going within 40 yards of them, they gave their war-cry and threw a number of spears, on which several of the party fired their carabines [sic], and generally with effect ${ }^{\prime} .^{94}$ Frederick Walker, first commander of the Queensland Native Mounted Police, referred to this halfmoon tactic when used in Queensland in the 1860s as 'stockyarding', linking it specifically to the most efficient use of spear throwers to concentrate a shower

\footnotetext{
89 Nettelbeck 1999: 224.

90 Whether or not any of these can be termed 'cemeteries' is a matter of conjecture, see Pardoe 1995; Littleton 1998; Hiscock 2008: 258-59.

91 Littleton et al. 2013.

92 Hemming 1984: 14.

93 Hawker Diary 13 May 1841 (SLSA PRG 209/2).

94 Deposition of John Allan in PRSAA 1843, Enclosure 3 in No. 87.
} 
of spears. ${ }^{95}$ More interestingly, after talking to people along the Murray during his time as Protector, Eyre described this as a tactic that was peculiar to attacks on European parties. ${ }^{96}$

\section{Other Aboriginal responses to violence}

Apart from their effective use of topography, the historical records suggest that a range of other strategies were also being employed by Aboriginal people to deal with the advent of Europeans into their territories. These were both conciliatory and retaliatory. Conciliatory responses included the nets, fish and women that were gifted by Aboriginal people to Europeans ${ }^{97}$ and the use of the European objects that were received in return to signal previous successful exchanges. Several glimpses illuminate an importance being given to European objects within Aboriginal systems of meaning. One of Eyre's potential conflict encounters was spurred by a large group of people 'crowding around us and the drays and ... handling everything they could get near, so that our whole time was taken up in watching them and in trying to keep them off ${ }^{\prime},{ }^{98}$ and Hawdon, Sturt and Buchanan all noted various attempts by Aboriginal people to remove portable items - notably cutlery, iron pots and other metal objects - from their camps ${ }^{99}$ indicating a general importance being attached to such items.

More specifically, the actions of Greybeard - one of the key early figures in the region - suggest the deliberate use of European items as strategic symbols of communication. In reflecting on Greybeard's murder, Sturt noted how he had 'made him a present, which he had preserved, and shewed to the first overland party that came down the river, and thenceforward ... became the guide of the parties that followed along that line' ${ }^{100}$ Although Hawdon failed to mention this moment, Greybeard was clearly using a carefully curated exotic object to signal his previous meeting with the only other European to have come through the region. In June 1838, Eyre noted that none of the hundreds of people he saw at the Rufus, including Greybeard, wore clothing of any kind, ${ }^{101}$ but when Sturt met with Greybeard two months later in August, he was wearing a European

\footnotetext{
95 Walker 1861: 149.

96 Eyre 1845: 224-25.

97 See various comments by Eyre, Sturt and others on the efficacy of peaceful means of negotiation, such as exchanging goods, particularly metal, for goodwill.

98 Eyre 1984: 157.

99 Buchanan 1923: 74; Hawdon 1952: 47-48; Sturt Diary 7 August 1838.

100 Sturt 1849: 86-87.

101 Eyre 1984: 157.
} 
frock shirt. ${ }^{102}$ As a self-appointed ambassador, Greybeard was often recorded as assisting parties in various instrumental ways, including in defusing tensions that could have erupted into violence. ${ }^{103}$ In this context, Greybeard's conscious decision to put on a frock shirt - mimicking the European deployment of such an item - may have signalled an important act of cross-cultural communication. For the Europeans the wearing of clothing connoted a range of deeply held normative values and therefore would have been read by them in particular, and to some extent reassuring, ways. Moreover, clothing would have signalled as such from a distance; something that may have been particularly meaningful in the context of encounters that had come perilously close to violence several times before. Within his own cultural context Greybeard's access to European goods would also have reinforced his status as a senior man, echoing the use of European coats and jackets by Aboriginal men in Sydney to fashion 'rough alliances' with individual Europeans, as well as more general symbols of the status of senior men as leaders and diplomats in forging alliances between Aboriginal groups. ${ }^{104}$

Certain retaliatory tactics were closely linked to these initial conciliatory ones. When Major O'Halloran, just before reaching the Rufus, asked one of their Aboriginal guides: 'Why did these blacks attack the Europeans?', they replied simply 'because the Europeans were in their territory' ${ }^{105}$ The answer was probably not so simple, although territorial ingress by Europeans was no doubt a primary catalyst. In this context, clothing again seems to have assumed a central role. Langhorne, after his attack in June 1841, noted that the bags of flour, tea and tobacco had been emptied on the ground, but all of the bedding, clothing and cooking utensils had been taken. ${ }^{106}$ The cooking utensils were presumably metal, but clothing seems a more unusual choice and hints at a continued importance being given to it in Aboriginal systems of meaning. At this time and in this place Aboriginal people had been successful at attacking two previous European parties (Inman's and Hawker's), so the removal of items from Langhorne's drays was no longer a signal of peaceful exchange but quite possibly the reverse: an indication of successful resistance. Unlike Greybeard's use of the frock shirt, in deliberately choosing clothing in this context Aboriginal men may well have been symbolically capturing items that had already acquired particular layers of meaning within an Aboriginal context but that were also highly personal to, and therefore valued by, the

102 Sturt Diary 5 August 1838. This was presumably given to him by Eyre, since he noted that he gave Greybeard a 'shirt, tomahawk and some other little presents' in February 1839, so perhaps also on his previous journey in June 1838, Eyre 1984: 187.

103 See, for example, Eyre 1984: 187; Sturt 1899: 150-51; Sturt Diary 5 August 1838.

104 Karskens 2011: 14, 30.

105 O'Halloran 1904: 78.

106 Langhorne to O'Halloran, June 22 1841, in PRSAA 1843, Enclosure 3 in No. 92: 282. 
Europeans in theirs. The testimony of the Adelaide interpreter, Pangki Pangki, may hint at another, more mundane, rationale when he uses the terms 'clothing' and 'blankets' interchangeably: 'The three natives said they would spear the Europeans and take away their clothing ... they showed fight for food and blankets.' ${ }^{107}$ Although we cannot know the precise range of meanings attributed to European clothing by Aboriginal people on the western Central Murray, it was certainly being targeted as a preferential resource.

Other, more esoteric responses are hinted at by the treatment that was meted out to the body of Martin, a member of Langhorne's party, after his death at the Rufus in 1841:

Thursday 24th June ... we were unable to make the River Rufus where Mr Langhorne's party was attacked till $1 / 2$ pt 3 pm; when we discovered to our horror that one of the four Europeans lately murdered by the Blacks ( \& all of whom had been thrown into the River by their Comrades) had been again hauled out of the water by the blacks, his thigh bones taken out, \& a green bough in mockery (as emblematic of peace) put into his right hand. ${ }^{108}$

This was a key moment in the sequence of events along the western Central Murray, but unfortunately the primary witnesses made no comment on the meaning of these actions at the time. Without direct Aboriginal testimony the placing of the green branch in Martin's hand is an ambiguous act. Green boughs elsewhere along the Darling and Murray (but also further to the north and south-east) were often used to signify a peaceful greeting to unfamiliar people, ${ }^{109}$ although their use was also context-dependant. Mitchell, for example, noted on the Darling that they were occasionally used by Aboriginal people to signal rejection and to deter him from any further interaction. ${ }^{110}$ The removal of Martin's thigh bones, however, suggests a sorcery motive. As a symbolic way of spearing a victim, pointing bones were typically made from long bones, ${ }^{111}$ and were important sorcery objects involved in projective magic. While there are no known direct references to this practice on the western Central Murray, Howitt noted that pointing bones on the Darling were sometimes made from human

107 Testimony of Pangki Pangki to Bench of Magistrates, 22 September 1841, in PRSAA 1843, Enclosure in No. 98: 302.

108 O'Halloran Diary 24 June 184la. His subsequent report to Grey described the entrails as also having been removed, O'Halloran to Grey, 27 June 1841, in PRSAA 1843, Enclosure 1 in No. 92: 279. Hawker (Diary 26 June 1841 [SLSA PRG 209/2]) claimed that Martin's heart was taken out, although he did not accompany $\mathrm{O}^{\prime}$ Halloran to the scene. Moorhouse only recorded the abdomen and chest as having been cut open, Moorhouse to Mundy, 30 June 1841, Protector's Letterbooks 1840-1857, SRSA GRG 52/7. Later versions by Bull added the removal of 'the vital organs, with the kidney fat', as well as the arm bones, Bull 1884: 226. For further discussion of Bull's additions, see Nettelbeck 1999.

109 Buchanan 1923: 67; Eyre 1984: 155-56; Hawdon 1952: 30-31; Lewis 2005.

110 Mitchell 1839: 245-46.

111 Although usually from animals rather than humans, see Walshe 2008. 
long bones ${ }^{112}$ and, according to Moorhouse, many of those involved in the Rufus River conflict came from the Darling 'and the country to the north of Lake Bonney' ${ }^{113}$ The removal of Martin's thigh bones may have been for just such a purpose, although whether directed against specific individuals or Europeans in general cannot be known. Reynolds has alluded to the significant symbolic role played by sorcery in Aboriginal resistance, arguing that it provided a powerful psychological mechanism by which Aboriginal people could attempt to influence otherwise inexorable and devastating events. ${ }^{114}$

Layered on top of this were the existing laws and customs relating to traditional land ownership. Early accounts ${ }^{115}$ make it clear that there were strict rules regarding entry to the various Aboriginal territories along the river, even where groups were welcoming of one another. In part, this system sometimes aided Europeans in their traversing of Aboriginal country, since representatives of each group would be delegated to accompany the parties and hand them on to their neighbours. ${ }^{116}$ In other ways, however, once relationships with European parties had broken down, such pre-existing relationships also formed the basis of cooperative resistance. The ethnohistorical record makes specific mention of such collaborative resistance in the Rufus River clash, for which Aboriginal people came from as far south and west as the Pound (see Figure 2), and as far north and east as the Darling. ${ }^{117}$ This makes it clear that it was more than just the Maraura who were caught up in these events.

\section{Conclusions}

In positing regionally specific paradigms for the responsibility of frontier violence, Rogers and Bain note that, in southern Australia, conflict was mainly perpetrated by convicts and settlers, whose behaviour was shaped by a deep racism and fears of victimhood centring around the isolated nature of shepherding and stock work. ${ }^{118}$ In northern Australia, however, where pastoral expansion took place outside of a convict labour system, the police, and specifically the Native Police, were the party responsible for most of the violence towards Aboriginal people. In analysing frontier violence holistically in this way, Rogers and Bain have noted the gap in this framework that is represented by South

\footnotetext{
112 Howitt 1904: 360; see also Elkin 1984: 45.

113 Southern Australian, 24 September 1841.

114 Reynolds 2006: 92-93.

115 E.g. Eyre's description of the 'meeting' at Moorundie of a group of 'neighbouring tribes' and the 'Lake Bonney' people and their 'friends', Eyre 1845: 219.

116 See, for example, Sturt 1833: 222; Moorhouse to Mundy, 30 June 1841, Protector's Letterbooks 1840-1857, SRSA GRG 52/7. See also Hemming 1984: 4 for a similar perspective.

117 Moorhouse to Mundy, 4 September 1841, Protector's Letterbooks 1840-1857, SRSA GRG 52/7.

118 Rogers and Bain 2016: 86.
} 
Australia: of all Australian frontiers, they argue that the early South Australian frontier is the least well known and speculate that it sits somewhere between the northern and southern paradigms because of its explicit exclusion of convicts and its ostensible humanitarian platform for dealing with Aboriginal people. ${ }^{119}$

What is clear from historical sources is that many of the stockmen in overlanding parties were former, and sometimes current, convicts, ${ }^{120}$ as well as pastoralists with interests in Victoria and New South Wales, which suggests that their behaviour and its consequences will have more in common with patterns associated with the southern paradigm than the exceptionalist claims made by South Australian governments or later proponents of Empire would suggest. ${ }^{121}$ Understanding the wider patterns of engagement across the western Central Murray between 1830 and 1841 makes it clear that frontier violence in this space was both sustained and highly complex. Fear, or at least anxiety, conditioned many European responses to travelling through this landscape, and even the earliest parties went armed and alert for trouble because of their prior experience. It was the initiation of the Overland Stock Route in 1838, bringing enormous quantities of men, arms, goods and stock within what was a highly territorialised Aboriginal landscape, that crystallised the tone of later encounters. Certainly many overlanders were undeterred and traversed the route more than once, including those who had been injured or attacked on previous occasions. This, combined with the proprietary attitude of Europeans towards their stock and possessions as precious sources of personal profit, was a deadly mix.

As layers of encounter built up along the route, attitudes towards Aboriginal people hardened and violence become ever more acutely anticipated. In many instances it was also self-fulfilling. O'Halloran's notes to himself on the second police expedition highlight the extent to which anxiety conditioned the response of his party to the danger around them:

When very close to the blacks avoid if possible a night atta[ck] from them, by moving after [dark?] into the scrub in single fil[e] \& by a winding route - Laying down armed \& saddled, with a double vidette dismounted upon the track at 150 or 200 yards from the main body - no fires, or if any black fires well concealed. With such rules well Enforced by the Officers \& steadily \& Coolly obeyed by the men - with Horses \& firearms in order \& 40 rounds of ammunition pr man, our party ought to route [sic] a thousand of the most determined \& active blacks. ${ }^{122}$

119 Rogers and Bain 2016: 86.

120 See, for example, Eyre 1838: 187; Hirst 2012: 125; Sturt 1833: 132.

121 See, for example, critical discussions of South Australian judicial policies in Foster 2013, Foster and Nettelbeck 2012 and Nettelbeck and Foster 2010b, as well as their analyses of the elisions of memory as squatters became settlers and settlers became citizens in Nettelbeck 1999 and Nettelbeck and Foster 2010a. 122 O'Halloran Diary 184lb, undated entry, emphasis in original. 
O'Halloran was well aware of the location of previous encounters; his precautions, while militarily precise, were echoed by others in various ways through similar expectations of violence along the route and the reactions that this evoked. For their part, Aboriginal people deployed a range of responses to deal with the new situation. These included reciprocity, the use of European goods, particularly clothing, as symbolic means of communication, sorcery, the particular tactic of 'stockyarding' - which may have been developed in direct response to European conflict - and effective collaboration with other, similarly affected, groups. From this it is clear that many western Central Murray groups were involved in, suffered from, and reacted to, contact-period violence.

Translating the information contained in primary and secondary accounts into a spatial representation of such behaviour has provided a means to analyse documentary sources in a way that is other than purely textual. In doing so, we have been able to add greater and new details to the existing literature on frontier conflict along the western Central Murray and show how certain spaces altered, affected or promoted certain actions. In seeking to approach the growing atmosphere of anxiety along the Overland Stock Route as a cartographic problem, this paper has explored some of the ways in which spatially visualising 'fuzzy' qualitative data can open up a space for additional reflection. ${ }^{123}$ One limitation of our emphasis on publicly available documents has necessarily led us to reconstruct the Overland Stock Route as a place of conflict largely from the European perspective. Later stages of this project, in collaboration with RMMAC, will explore the material correlates of wider Aboriginal responses to European presence along the western Central Murray throughout the nineteenth century. One clear outcome of this project has been that the early contact period violence - regardless of how endemic and widespread it was - does not seem to have been the immediate cause of the drastic reduction in people who survived to have descendants. This raises questions about the nature and tone of encounters in this region once the violence of the Overland Stock Route transitioned to relationships associated with pastoral properties and permanent settlement. A number of oral histories and other accounts exist that make reference to individuals as survivors of massacres in this region ${ }^{124}$ and it is the later contact history and the narratives of RMMAC members that will be explored in the future. The ways in which Aboriginal people 'made culturally determined and perhaps individual choices' in response to contact and conflict is the story of the accommodations generated across the frontier. ${ }^{125} \mathrm{As}$ a process, the frontier

123 Cooper and Gregory 2011: 98.

124 Martin 1997.

125 Broome 1994: 76 . 
was constituted by the various boundaries that were recognised, negotiated or ignored on both sides - leaving little room for mutual understanding - and the dispossession that lay at the heart of the imperial project.

\section{Acknowledgements}

We would like to thank the members of the River Murray and Mallee Aboriginal Corporation for working with us on the Calperum Project and for permission to conduct the research that was involved in this project. Kym Hardwick from the South Australian Police Historical Society kindly provided electronic copies of O'Halloran's June diary. The reviewers of this paper made very constructive suggestions that greatly improved its argument and flow.

\section{References}

\section{Archival sources}

Bonney, Charles n.d., Autobiographical notes. Unbound typescript, electronic version, nla.gov.au/nla.aus-vn5151802, accessed 10 July 2015.

Crawford, James Coutts 1839, Diary 1838-1839, Papers M600, M687-688, 1837-1880, National Library of Australia.

Hawker, James C. 1841-1845, Journal of J. C. Hawker of an expedition made to the River Murray against the natives in order to recover sheep (and) to protect another overland party, PRG 209/2, State Library of South Australia.

1846, Extracts from the diary of James Collins Hawker 1841-1848, undated typescript, Borrow Collection, Flinders University.

Mack, Joseph Kingsley n.d., Notes and clippings, PRG 1470 series 6/3-9 and series 7/13-, State Library of South Australia.

Moorhouse, Matthew 1841, Protector's Letterbooks - Volume 1. 21 May 1840-6 January 1857, GRG 52/7, State Records of South Australia.

O'Halloran, T.S. 1841a, Major T.S. O'Halloran's diary of his punitive expeditions to the River Rufus, Volumes I and II, GRG 5/81, State Records of South Australia.

1841b, Journal Rpt on an Expedition from Adelaide Along the River Murray to the Rufus \& Lake Victoria, South Australia Police Historical Society, Adelaide. 
Sturt, Charles 1829-1830, Chart of the Murray River, Sheets 7-18, PRG 2/12/1 Part 1, item 7, State Library of South Australia.

1838, Documents of the overland journey down the Hume \& Murray, PRG 2/1/1, State Library of South Australia.

\section{Newspapers}

Observer, 7 April 1923, 'Overlanding cattle in the days of the pioneers': 50, 51.

South Australian Gazette and Colonial Register, 21 July 1838, 'Mr Eyre's journey overland from New South Wales to Adelaide (South Australia)': 3.

South Australian Register, 26 October 1839, 'Overland arrival': 5.

- 16 November 1839, 'The natives on the Murray': 4, 5.

— 30 November 1839, 'Murder of Mr Mackinnon's stockman': 5.

— 5 September 1840, 'Another overland arrival': 2.

- 18 August 1849, 'Quarterly police report': 3-4.

Southern Australian, 9 July 1841, 'Expected overland parties': 3.

- 24 September 1841, 'The Bench of Magistrates and the late fatal affray with the natives': 3 .

— 10 June 1842, 'Mr Eyre's visit to the Rufus and Lake Victoria': 2, 3.

\section{Published sources}

Attwood, Bain and S.G. Foster 2003, 'Introduction' in Frontier Conflict: The Australian Experience, Bain Attwood and S.G. Foster (eds), National Museum of Australia, Canberra: 1-29.

Barker, Bryce 2007, 'Massacre, frontier conflict and Australian archaeology', Australian Archaeology 64: 9-14.

Berndt, Ronald and Catherine Berndt with John Stanton 1993, A World that Was: The Yaraldi of the Murray River and the Lakes, South Australia, Melbourne University Press, Melbourne.

Brennan-Horley, Chris, Susan Luckman, Chris Gibson and Julie WilloughbySmith 2010, 'GIS, ethnography and cultural research: Putting maps back into ethnographic mapping', The Information Society: An International Journal 26(2): 92-103. 
Broome, Richard 1994, 'Aboriginal victims and voyagers: Confronting frontier myths', Journal of Australian Studies 42: 70-77.

Buchanan, Alexander 1923, 'Diary of a journey overland from Sydney to Adelaide with sheep. July-December 1839', Proceedings of the Royal Geographical Society of Australasia: South Australian Branch 24(1922-23): 50-76.

Bull, John Wrathall 1884, Early Experiences of Life in South Australia and an Extended Colonial History, E.S. Wigg and Son, Adelaide.

Cole, Noelene 2010, 'Painting the police: Aboriginal visual culture and identity in colonial Cape York Peninsula', Australian Archaeology 71: 17-28.

Cooper, David and Ian N. Gregory 2011, 'Mapping the English Lake District: A literary GIS', Transactions of the Institute of British Geographers 36: 89-108.

Crawford, James Coutts 1880, Recollections of Travel in Australia and New Zealand, Truebner and Co., London.

Curr, E.M. 1886, The Australian Race, Government Printer, Melbourne.

Curthoys, Anne and John Docker 2001, 'Introduction - Genocide: Definitions, questions, settler-colonies', Aboriginal History 25: 1-15.

Elkin, Adolphus P. 1984, Aboriginal Men of High Degree, University of Queensland Press, St Lucia.

Evans, Ray 1993, 'The blood-dimmed tide. Frontier violence and Aboriginal resistance', in Race Relations in Colonial Queensland, Ray Evans, Kay Saunders and Kathryn Cronin (eds), University of Queensland Press, St Lucia: 33-46.

Eyre, Edward John 1845, Journals of Expeditions of Discovery into Central Australia, and Overland from Adelaide to King George's Sound, in the Years 1840-1; Sent by the Colonists of South Australia, with the Sanction and Support of the Government: Including an Account of the Manners and Customs of the Aborigines and the State of Their Relations with Europeans, Volume II, T. and W. Boone, London.

1984, Autobiographical Narrative of Residence and Exploration in Australia 1832-1839 by Edward John Eyre. Edited with an Introduction and Notes by Jill Waterhouse, Caliban Books, London.

Fels, Marie 1988, Good Men and True: The Aboriginal Police of the Port Phillip District 1837-1853, Melbourne University Press, Carlton. 
Finnane, Mark and Jonathan Richards 2004, "You'll get nothing out of it"? The inquest police and Aboriginal deaths in colonial Queensland', Australian Historical Studies 35: 84-105.

Foster, Robert 1989, 'Feasts of the full-moon: The distribution of rations to Aborigines in South Australia: 1836-1861', Aboriginal History 13(1): 63-78.

2009, "Don't mention the war". Frontier violence and the language of concealment', History Australia 6(3): 68.1-68.15.

2013, 'His Majesty's most gracious and benevolent intentions', Journal of Australian Colonial History 15: 105-20.

Foster, Robert, Rick Hosking and Amanda Nettelbeck 2001, Fatal Collisions: The South Australian Frontier and the Violence of Memory, Wakefield Press, Adelaide.

Foster, Robert and Amanda Nettelbeck 2012, Out of the Silence: The History and Memory of Australia's Frontier Wars, Wakefield Press, Adelaide.

Gerstäcker, Friedrich 1853, Narrative of a Journey Round the World Comprising a Winter Passage Across the Andes to Chili; with a Visit to the Gold Regions of California and Australia, the South Sea Islands, Java, \&c, Harper and Brothers, Publishers, New York.

Gibson, Chris, Chris Brennan-Horley and Andrew Warren 2010, 'Geographic Information Technologies for cultural research: Cultural mapping and the prospects of colliding epistemologies', Cultural Trends 19(4): 325-48.

Great Britain, Parliament, House of Commons 1843, Papers Relative to South Australia, Aborigines, Printed by William Clowes for HMSO, London, 267-310.

Gregory, Ian N. and Richard G. Healey 2007, 'Historical GIS: Structuring, mapping and analysing geographies of the past', Progress in Human Geography 31(5): 638-53.

Hawdon, Joseph 1952, The Journal of a Journey from New South Wales to Adelaide (The Capital of South Australia), Georgian House, Melbourne.

Hemming, Steve 1984, 'Conflict between Aborigines and Europeans along the Murray River, the Darling to the Great South Bend (1830-1841)', Journal of the Anthropological Society of South Australia 22(1): 3-23.

Hirst, John 2012, 'South Australia and Australia: Reflections on their histories', in Turning Points. Chapters in South Australian History, Robert Foster and Paul Sendziuk (eds), Wakefield Press, Adelaide: 118-130. 
Hiscock, Peter 2008, The Archaeology of Ancient Australia, Routledge, London.

Hogg, Robert 2011, “The most manly class that exists": British gentlemen on the Queensland frontier', Journal of Australian Colonial History 13: 65-84.

Horton, David 1994, The Encyclopaedia of Aboriginal Australia: Aboriginal and Torres Strait Island History, Society and Culture, AIATSIS, Canberra.

Howitt, Alfred William 1904, The Native Tribes of South-east Australia, Macmillan, London.

Karskens, Grace 2011, 'Red coat, blue jacket, black skin: Aboriginal men and clothing in early New South Wales', Aboriginal History 35: 1-36.

Kwan, Mei-Po and Guoxiang Ding 2008, ‘Geo-narrative: Extending Geographic Information Systems for narrative analysis in qualitative and mixed-method research', The Professional Geographer 60(4): 443-65.

Lewis, Darrell 2005, “'Invaders of a peaceful country": Aborigines and explorers on the Lower Victoria River, Northern Territory', Aboriginal History 29: 23-45.

Litster, Mirani and Lynley A. Wallis 2011, 'Looking for the proverbial needle? The archaeology of Australian colonial frontier massacres', Archaeology in Oceania 46: 105-17.

Littleton, Judith 1998, 'East and west: Burial practices along the Murray River', Archaeology in Oceania 34: 1-14.

Littleton, Judith, Keryn Walshe and John Hodges 2013, 'Burials and time at Gillman Mound, northern Adelaide, South Australia', Australian Archaeology 77: 38-51.

Martin, Sarah 1997, Lake Victoria EIS, Anthropological Report. A report prepared for the NSW Department of Land and Water Conservation and the Murray-Darling Basin Commission.

McLean, James 1903, 'Police experiences with the Natives. Reminiscences of the early days of the colony', Proceedings of the Royal Geographical Society of Australasia, South Australian Branch 6(1902-03): 66-92.

Mitchell, Thomas Livingstone 1839, Three Expeditions into the Interior of Eastern Australia: with Descriptions of the Recently Explored Region of Australia Felix, and of the Present Colony of New South Wales, T. \& W. Boone, London.

Nettelbeck, Amanda 1999, 'Mythologising frontier: Narrative versions of the Rufus River conflict, 1841-1899', Journal of Australian Studies 23(61): 75-82, 224-226. 
Nettelbeck, Amanda and Robert Foster 2010a, 'Commemorating Foundation: A study in regional historical memory', History Australia 7(3): 53.1-53.18.

2010b, 'Colonial judiciaries, Aboriginal protection and South Australia's policy of punishing "with exemplary severity"', Australian Historical Studies 41(3): 319-36.

O'Halloran, Thomas 1904, ‘From Adelaide along the River Murray to the Rufus and Lake Victoria', Proceedings of the Royal Geographical Society of Australasia: South Australian Branch 7(1903-04): 70-91.

Pardoe, Colin 1995, 'Riverine, biological and cultural evolution in southeastern Australia', Antiquity 69(265): 696-713.

Pike, D.H. 1965, 'The diary of James Coutts Crawford: Extracts on Aborigines and Adelaide, 1839 and 1841', South Australiana IV(1): 3-15.

Radcliffe-Brown, A.R. 1918, 'Notes on the social organization of Australian tribes', Journal of the Royal Anthropological Institute 48: 222-53.

Reynolds, Henry 2001, An Indelible Stain? The Question of Genocide in Australia's History, Viking, Melbourne.

2006, The Other Side of the Frontier: Aboriginal Resistance to the European Invasion of Australia, UNSW Press, Sydney.

Richards, C. 1903, 'The Marraa' Warree' tribes or nation and their language. With an account of how a new tribe was formed among them', Science of Man 6: 119-26, 163-69.

Richards, Jonathan 2008, The Secret War: A True History of Queensland's Native Police, University of Queensland Press, Brisbane.

Rogers, Thomas James and Stephen Bain 2016, 'Genocide and frontier violence in Australia', Journal of Genocide Research 18(1): 83-100.

Ryan, Lyndall 2008, 'Massacre in the Black War in Tasmania 1823-34: A case study of the Meander River region, June 1827', Journal of Genocide Research 10(4): 479-99.

2010, 'Settler massacres on the Port Phillip frontier, 1836-1851', Journal of Australian Studies 34(3): 257-73.

2013, 'Untangling Aboriginal resistance and the settler punitive expedition: The Hawkesbury River frontier in New South Wales, 1794-1810', Journal of Genocide Research 15(2): 219-32. 
Silliman, Stephen 2005, 'Culture contact or colonialism? Challenges in the archaeology of native North America', American Antiquity 70(1): 55-74.

Smyth, Robert Brough 1878, The Aborigines of Victoria: with Notes Relating to the Habits of the Natives of Other Parts of Australia and Tasmania Compiled from Various Sources for the Government of Victoria, 2 vols, John Ferres Trubner and Co., Melbourne/London.

Snead, James 2011, "The "secret and bloody war path": movement, place and conflict in the archaeological landscape of North America', World Archaeology 43(3): 478-92.

Spooner, P.G., M. Firman and Yalmambirra 2010, 'Origins of Travelling Stock Routes, 1. Connections to Indigenous travel pathways', The Rangeland Journal 32: 329-39.

Sturt, Charles 1833, Two Expeditions into the Interior of Southern Australia During the Years 1828, 1829, 1830, 1831 with Observations on the Soil, Climate and General Resources of the Colony of New South Wales, Smith, Elder and Co., London. Project Gutenberg edition, gutenberg.net.au/ebooks/e00059.html.

1849, Narrative of an Expedition into Central Australia, Performed Under the Authority of Her Majesty's Government During the Years 1844, 5 and 6, Together with a Notice of the Province of South Australia in 1847, Volume 1, T. and W. Boone, London.

Sturt, Napier George Mrs 1899, Life of Charles Sturt: Sometime Capt. 39th Regt. and Australian Explorer, Smith, Elder, London.

Taplin, George (ed.) 1879, The Folklore, Manners, Customs and Languages of the South Australian Aborigines: Gathered from the Inquiries made by Authority of South Australian Government, Government Printer, London.

Tindale, Norman B. 1940, 'Results of the Harvard-Adelaide Universities Anthropological Expedition, 1938-1939. Distribution of Australian tribes: A field survey', Transactions of the Royal Society of South Australia 64(1). 1974, Aboriginal Tribes of Australia, ANU Press, Canberra.

Tolmer, Alexander 1882, Reminiscences of an Adventurous and Chequered Career at Home and at the Antipodes. Vol. 1, Sampson Low, Marston, Searle and Rivington, London.

Towers, George 2010, 'Rediscovering rural Appalachian communities with historical GIS', Southeastern Geographer 50(1): 58-82. 
Walker, Frederick 1863, 'Journal of Mr. Walker from the day he left Macintosh's Station, on the Nogoa, to that of his arrival at the Albert River, Gulf of Carpentaria', Journal of the Royal Geographical Society of London 33: 133-50.

Walshe, Keryn 2008, 'Pointing bones and bones points in the Australian Aboriginal Collection of the South Australian Museum', Journal of the Anthropological Society of South Australia 33: 167-203.

Webster, John 1987, Reminiscences of an Old Settler in Australia and New Zealand, Southern Reprints, Papakura, NZ.

Williamson, Christine 2002, 'Finding meaning in the patterns: The analysis of material culture from a contact site in Tasmania', in After Captain Cook: The Archaeology of the Recent Indigenous Past in Australia, Rodney Harrison and Christine Williamson (eds), Archaeological Method Series 8, University of Sydney, Sydney: 76-101.

Woollacott, Angela 2009, 'Frontier violence and settler manhood', History Australia 6(1): 11.1-11.15. 
This text is taken from Aboriginal History, Volume 40, 2016, edited by Liz Conor, published 2016 by ANU Press,

The Australian National University, Canberra, Australia. 